\title{
Influence of socioeconomic lifestyle factors and genetic polymorphism on type 2 diabetes occurrences among Tunisian Arab and Berber groups of Djerba Island
}

\author{
This article was published in the following Dove Press journal: \\ Pharmacogenomics and Personalized Medicine \\ 20 August 2009 \\ Number of times this article has been viewed
}

\author{
Thouraya Baroudi Ouederni' \\ Ahmed Fadiel ${ }^{2,3}$ \\ Nejla Stambouli' \\ Trudy J Scalize ${ }^{3}$ \\ Hedi Ben Maiz ${ }^{4}$ \\ Hafaona Kammoun Abid' \\ Rim Bouhaha' \\ Jose Sanchez-Corona ${ }^{5}$ \\ Adel Hamza ${ }^{1,6^{*}}$ \\ Amel Benammar-Elgaaied 1," \\ 'Laboratory of Genetics, Immunology \\ and Human Pathology, Faculty \\ of Sciences of Tunis, Tunis, Tunisia; \\ ${ }^{2}$ New York University School \\ of Medicine, NYU Medical Center, \\ New York, NY, USA; ${ }^{3}$ Biomedical \\ Informatics, OBGYN Department, \\ Meharry Medical College, Nashville, \\ TN, USA; ${ }^{4}$ Charles Nicolle Hospital, \\ Internal Medicine A, Tunis, Tunisia; \\ ${ }^{5}$ División de Medecina Molecular, \\ Centro de Investigación Biomédica \\ de Occidente, Instituto Mexicano \\ Del Seguro Social, Guadalajara, \\ Jalisco, México; ${ }^{6}$ Department of \\ Pharmaceutical Sciences, College of \\ Pharmacy, University of Kentucky, \\ Lexington, KY, USA; *These authors \\ contributed equally to this work and \\ are the corresponding authors
}

Correspondence: Adel Hamza Department of Pharmaceutical Sciences, College of Pharmacy, University of Kentucky, Lexington, KY, USA Email ahamz3@email.uky.edu

\begin{abstract}
Type 2 diabetes mellitus (T2DM) is characterized by three major metabolic abnormalities: impaired insulin-stimulated glucose uptake in muscle and adipose tissues, alterations in glucose-stimulated insulin secretion, and increased hepatic glucose production. Both genetic and environmental factors contribute to its development. The insulin gene (INS), insulin receptor gene (INSR), and insulin receptor substrate 1 gene (IRS1), identified by polymerase chain reaction and digestion with selected restriction enzymes PstI, NsiI, and BstnI, have been proposed as T2DM candidate genes. To determine the contribution of genetic and environmental factors on the occurrence of T2DM, we examined the frequency of T2DM among two ethnically diverse populations, Arabs and Berbers, who have shared the same environment, the island of Djerba, for thousands of years. Both populations have a high prevalence of obesity,T2DM, and a high consanguinity rate. A total of 162 T2DM men and women were matched to 110 healthy male and female controls. Results showed that the NsiI polymorphism in INSR and BstnI polymorphism of IRSI were significantly associated with T2DM only among the Berber group. The PstI polymorphism in INS, was not associated with T2DM in either group. Sedentary lifestyles, lower physical activity, and lower educational levels were associated with T2DM among the Berber group. These findings suggest that the insulin receptor gene and lifestyle factors in combination may contribute to the occurrence of T2DM in the Berber portion of this island population.
\end{abstract}

Keywords: polymorphism, insulin, insulin receptor, lifestyle, insulin receptor substrate-1, Berbers, Arabs, Djerba Island

\section{Introduction}

Type 2 diabetes mellitus (T2DM) is a multifactorial disease resulting from an interaction between genetic and environmental factors. ${ }^{1}$ Age, physical activity patterns, dietary habits, lifestyle and obesity play a crucial role in the modulation of the disease occurrence. The predisposition to this disease is thought to be conferred by a number of different genes that in isolation may have only minor effects, but in combination lead to the characteristic pathophysiological effects. ${ }^{2}$ This genetic susceptibility may be conferred by an unfavorable combination of individual polymorphisms in the genes involved, each one controlling part of the pathogenic process. ${ }^{3}$ These genes are defined as "diabetogenes" complex that play a key role in glucose metabolism and others involved in the signal transduction characterizing insulin's biological activity. ${ }^{8}$ These genes are the insulin 
gene (INS), the insulin receptor gene (INSR), and the insulin receptor substrate 1 gene $(I R S 1)^{5}$ in which several polymorphisms (single-nucleotide polymorphisms [SNPs]) have been described. Some of these SNPs have been associated with T2DM. A polymorphism of interest in the INS gene is the PstI RFLP at position 1367 of the $3^{\prime}$ untranslated region. ${ }^{9,10}$ In the INSR gene, the NsiI RFLP at exon 8 , has been associated with arterial hypertension. ${ }^{11}$ Finally, the IRS1 gene presents a polymorphism located at codon 972 (Bstn I RFLP), ${ }^{12}$ which has been associated with both T2DM and insulin resistance. ${ }^{12,13}$

Studies have investigated polymorphisms associated with T2DM and found that among heterogeneous populations throughout the world, there are similar polymorphisms that convey genetic risks for T2DM in subgroups of main populations, ie, Mexican Americans, Pima Indians, gypsies of southern Slovakia, African Americans, to name a few. This feature has been reported in cases of isolated ethnic groups $^{14-18}$ and among disadvantaged groups in developed countries. ${ }^{19}$

Here we focus on well defined neighboring populations belonging to two ethnic groups from the Djerba Island in Southeastern Tunisia. Despite the integration of the socioculturally diverse civilizations over hundreds of years, ethnic separation remains a part of everyday life in Tunisia, mostly due to the different practices of the Muslim religion. Thus, the two populations maintain their separate cultures and ways of life although they share an agricultural and artisans economy. Despite their differences, both Arab and Berber groups show a high prevalence of T2DM, obesity, high consanguinity rate, and metabolic syndrome characteristics. Consequently, this environment provides the opportunity to investigate the effect of lifestyle on T2DM occurrence in association with genetic polymorphisms. We, therefore, randomly sampled the population to examine RFLPs at the INS, INSR, and IRS1 genes and the correlation between T2DM and particular environment risk factors for each ethnic group.

\section{Materials and methods Subjects}

Unrelated men and women of Arab and Berber descent (172 Arab Tunisians and 100 Berber Tunisians) originating from the Island of Djerba were recruited from the Department of Endocrinology of Midoun and Houmet Essouk Hospital (for Arabs) and the Department of Endocrinology of Guellala and Sedwich Hospital (for Berbers). Healthy controls were recruited from the local villages throughout the Island.
Arabs and Berbers were divided into two groups according to their diagnosis of T2DM. Inclusion criteria required that participants were of adult age, had lived on the island their entire lives, and that their partner was of the same ethnicity and had been born and raised on the island as well.

\section{Clinical intake and medical histories}

Clinical features and family history of diabetes were collected by questionnaire and interviews. Fasting glycemic status was checked for each participant. Randomly selected individuals had fasting glucose $<6.1 \mathrm{mmol} / 1$ and did not suffer from any other disease. Weight and height were measured on barefoot and lightly clothed subjects. Body mass index (BMI; $\mathrm{kg} / \mathrm{m}^{2}$ ) was calculated and obesity was defined as BMI $\geq 30 \mathrm{~kg} / \mathrm{m}^{2} .{ }^{19}$ Hypertension was defined as a systolic pressure $\geq 140 \mathrm{mmHg}$ or diastolic pressure $\geq 90 \mathrm{mmHg}$. The characteristics of the two groups are presented in Table 1. Venous blood samples were drawn for determination of plasma glucose and DNA extraction.

\section{Questionnaires and interviews}

For each subject, a questionnaire about lifestyle, age, education level, and physical activity was administered. Usual dietary intake was assessed with the use of a semi-quantitative food-frequency questionnaire (FFQ). The FFQ consisted of a list of foods with a standard serving size. Participants were asked to report their frequency of consumption of each food item during the previous year on a daily, weekly or monthly basis. Portion sizes of consumed foods were converted from household measures to grams. Each food and beverage was then coded according to the prescribed protocol and analyzed for content of energy and the other nutrients by weight using Bilnut software (INSERM; Nutrisoft, Cerelles, France), which was adapted for Tunisian foods.

Two measures of socioeconomic level status were used: 1) Level of education was measured as number of years spent in the education system, eg, primary school, secondary school, and high school, in contrast to nonreading analphabets. 2) Socioeconomic status was based on a questionnaire that asked about material possessions within the household, eg, water pipeline; two TV sets, toilet that can be flushed, bathroom, computer, gas/central heating, telephone, car, freezer, another apartment, video recorder.

For physical activity assessment, subjects completed a physical-activity-recall questionnaire. They were asked to record whether they are sleeping, sitting, standing, or watching television during each hour of the day. Subjects noted the time of day they started each new activity, body position 


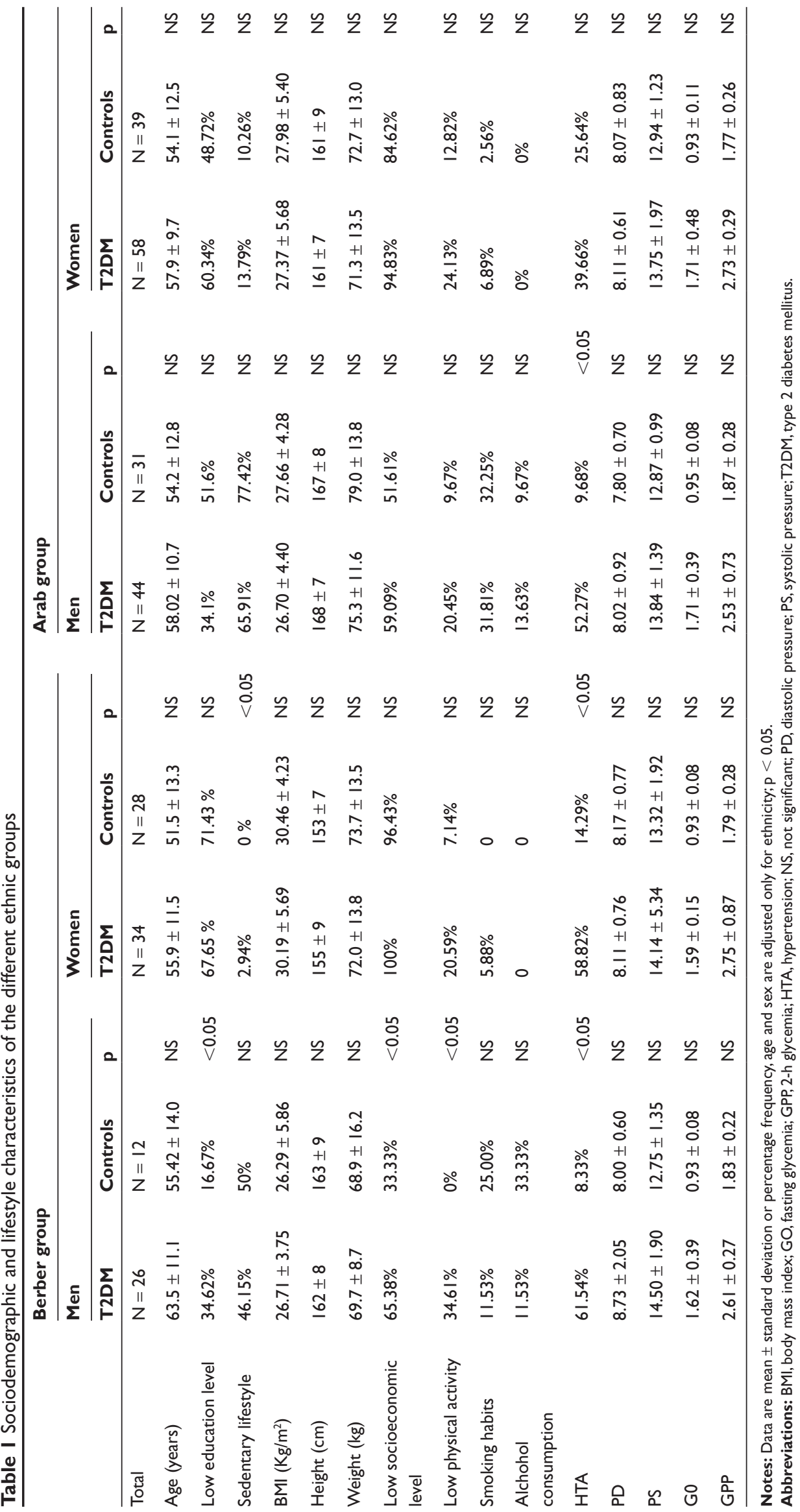


during the activity (reclining, sitting, standing, or walking), effort (light, moderate, vigorous). They were asked about both leisure and occupational physical activity performed over the past week. For the past week, the average number of hours per week of each activity was calculated. The total hours of each activity were multiplied by the estimated metabolic cost (EMC) of the activity then, the physical activity level (PAL) was computed as the total energy expended over 24 hours divided by 24 . Gender, age, height and body weight are the main determinants of basal metabolic rate (BMR). To estimate the BMR we used predictive equations based on these factors. By multiplying the PAL by the BMR, the total energy expenditure (TEE) was determined.

All procedures involved in the current study were reviewed and approved by the Ethics Committee of the Medicine University of Tunis. All study subjects signed informed consents.

\section{Methods}

Genomic DNA was isolated from peripheral blood by phenol extraction. ${ }^{20}$ Polymerase chain reaction (PCR) was performed using three primer pairs corresponding to respectively: the $3^{\prime}$ untranslated region of the INS gene, exon 8 of the INSR gene, and the region encompassing codon 972 of the IRS1 gene. Two sequence-specific oligonucleotide primers were used for the polymerase chain reaction: the $3^{\prime}$ primer (5'AGGCGTGGCATTGTGCCA3') was used in combination with the $5^{\prime}$ primer $\left(5^{\prime} \mathrm{CTGGGAGGGGCTC-}\right.$ CAAGT $3^{\prime}$ ) for the insulin gene, for the receptor of the insulin we used the $3^{\prime}$ primer $\left(5^{\prime}\right.$ CGGTCTTGTAAGGGTAACTG3') was used in combination with the $5^{\prime}$ primer (5'GAATTCACATTCCCAAGACA3') and for the insulin receptor substrate 1 gene we used the $3^{\prime}$ primer $\left(5^{\prime} \mathrm{CTTCT}-\right.$ GTCAGGTGTCCATCC3') was used in combination with the $5^{\prime}$ primer (5'TGGCGAGGTGTCCACGTAGC3') These primers have been designed at Centro de Investigación Biomédica de Occidente in Mexico. Amplified products were digested with the corresponding restriction enzymes: Pst $\mathrm{I}$ for the INS gene, NsiI for the INSR gene, and BstnI for the IRSI gene amplicons. The digestion products were resolved by polyacrylamide gel electrophoresis and visualized by silver staining. ${ }^{21,22}$

\section{Statistical analysis}

The statistical software SPSS version 10.0 (SPSS Inc., Chicago, IL, USA) was used to analyze variables of the Arab and Berber groups relative to T2DM. The EPI INFO 6 package program (Centers for Disease Control and
Prevention, Atlanta, GA, USA) was used to compare allelic and genotypic frequencies in diabetic patients and controls performing the Student's $t$-test, the Pearson's $\chi^{2}$ tests and the Fisher's exact test (when genotype class was below 5). Odds ratios (OR) are given with their corresponding 95\% confidence intervals (CI). A p value of $<0.05$ was considered to be statistically significant. Intakes were calculated with Bilnut software (Bilnut 4.0; Nutrisoft), which was adapted for Tunisian foods, for total energy, protein, carbohydrates (total, sucrose), fat (total, saturated, poly and monounsaturated), fiber, calcium, magnesium, sodium, phosphorus, animal to vegetable protein ratios, and polyunsaturated to saturated fat ratios.

\section{Results}

\section{Sociodemographic and lifestyle characteristics}

We compared the clinical (BMI and arterial pressure) characteristics of 162 T2DM patients and 110 healthy control subjects belonging to Berber and Arab groups of Djerba Island (Table 1). The mean age of the Arab T2DM group was $57.96 \pm 10.09$ and $54.13 \pm 12.53$ years for Arab controls. The mean age of the Berber T2DM group was $59.2 \pm 11.85$ and $52.70 \pm 13.44$ years for controls. Age was not significantly different for the groups as expected due to the matching design used. Results revealed a significant difference in educational levels between these two groups. In comparison with the Arabs, the Berbers had a lower level of education (Table 1) with a significant difference between Berber men and women. The Berber T2DM male's socioeconomic level was significantly higher $(\mathrm{p}<0.050)$ than controls. There was no significant difference in the Arab groups.

The prevalence of low physical activity was significantly higher among the Berber male group than the Arab male group; likewise, the prevalence of sedentary lifestyle was higher among the Berbers group compared to that of the Arabs. There was no difference in alcohol consumption and no significant difference in smoking habits between patients and controls (Table 1).

\section{Caloric intakes}

Table 2 presents mean dietary intake by ethnic groups for males and females, respectively. Mean caloric intakes among Arab males were $1846 \pm 262 \mathrm{kcal}$. Caloric intakes among Berber males were $2039 \pm 316 \mathrm{Kcal}$. For females, caloric intakes were $1833 \pm 254 \mathrm{Kcal}$ for Arabs and $1858 \pm 239$ kcal for Berbers. Mean caloric intakes for Arab subjects were 
$1839 \pm 256$ while it was $1927 \pm 283$ for Berber subjects. There were no significant ethnic differences in caloric intake in either sex group.

\section{Macronutrient intakes}

Average protein intake for each group was $56 \mathrm{~g}, 65 \mathrm{~g}$, $55 \mathrm{~g}$, and $57 \mathrm{~g}$ for Arab men, Berber men, Arab women, and Berber women, respectively (Table 2). There was no significant difference among women of either groups when compared by ethnicity but there was a significant difference $(p<0.02)$ between Arab and Berber men. Nevertheless, the animal protein to vegetable protein ratio was significantly greater in the Arab group (men and women) than Berber group ( $\mathrm{p}<0.03$ ).

Average carbohydrate consumption showed no statistical significance across groups when compared by ethnicity. However the Arab group consumed more sucrose than the Berber group $(\mathrm{p}<0.02)$ and the Berber group consumed more fiber than the Arab group $(\mathrm{p}<0.02)$. There was a positive correlation between calories and fiber intake $(r=0.55$; $\mathrm{p}<0.001)$ and a negative correlation between fiber and sucrose intake $(r=-0.33 ; p<0.001)$.

\section{Prevalence of overweight and of reported morbidity}

Prevalence of overweight was higher among the Berber women than among the Arabs, but the difference was not significant between T2DM cases and controls (Table 1). There was no significant difference in height and weight between the two groups. There was a significant difference in hypertension in the two groups. There was no significant difference between diastolic and systolic pressure.

\section{Comparison between Arab and Berber}

\section{allelic and genotypic distribution}

Polymorphism of three genes was analyzed in 162 patients and 110 controls: PstI polymorphism in nucleotide 1367 of the $3^{\prime}$ untranslated regions of the insulin gene, ${ }^{23}$ NsiI polymorphism in exon 8 at nucleotide 6224 of the insulin receptor gene ${ }^{24}$ and BstnI polymorphism at codon 972 in the coding region of the insulin receptor substrate 1 gene. ${ }^{25}$

To assess associations between these described polymorphisms and T2DM, we analyzed the allelic and genotypic frequencies in patients and healthy controls belonging to Arab and Berber subgroups in Djerba.

Table 2 Dietary intakes in different ethnic groups

\begin{tabular}{|c|c|c|c|c|c|c|}
\hline & \multicolumn{3}{|l|}{ Arab group } & \multicolumn{3}{|c|}{ Berber group } \\
\hline & Men & Women & Total & Men & Women & Total \\
\hline Energy expenditure (cal/day) & $2293 \pm 230$ & $1825 \pm 154$ & $2044 \pm 304$ & $2404 \pm 574$ & $1832 \pm 188$ & $2027 \pm 454$ \\
\hline Total energy intake (cal/day) & $1966 \pm 185$ & $1922 \pm 215$ & $1943 \pm 20 \mid$ & $2069 \pm 232$ & $1951 \pm 152$ & $1991 \pm 189$ \\
\hline Protein (g/day) & $56 \pm 10$ & $55 \pm 11$ & $55 \pm 11$ & $65 \pm 14^{3}$ & $57 \pm 11$ & $60 \pm 13$ \\
\hline Protein (\% TEI ) & $12.1 \pm 1.5$ & $12.1 \pm 1.8$ & $12.1 \pm 1.6$ & $12.8 \pm 1.7$ & $12.3 \pm 1.5$ & $12.5 \pm 1.5$ \\
\hline AP/VP & $0.81 \pm 0.30$ & $0.80 \pm 0.33$ & $0.81 \pm 0.32^{\prime}$ & $0.71 \pm 0.44$ & $0.65 \pm 0.27$ & $0.67 \pm 0.30$ \\
\hline Fat (g/day) & $68 \pm 18$ & $70 \pm 14$ & $69 \pm 16^{1}$ & $83 \pm 19^{3}$ & $70 \pm 14$ & $78 \pm 17$ \\
\hline Fat (\% TEI) & $33.5 \pm 6.0$ & $34.5 \pm 3.8$ & $34.0 \pm 4.9^{\prime}$ & $36.7 \pm 4.7$ & $36.4 \pm 4.4$ & $36.5 \pm 4.5$ \\
\hline SFA (g/day) & $17.4 \pm 5.8$ & $18.2 \pm 4.9$ & $17.7 \pm 5.3$ & $18.8 \pm 4.8$ & $17.9 \pm 5.6$ & $18.2 \pm 5.3$ \\
\hline SFA (\% TEI) & $7.8 \pm 2.3$ & $8.5 \pm 2.0$ & $8.2 \pm 2.2$ & $8.2 \pm 1.5$ & $8.2 \pm 2.3$ & $8.2 \pm 2.0$ \\
\hline MUFA (g/day) & $43.6 \pm 12.1$ & $43.3 \pm 9.7$ & $43.4 \pm 10.7^{1}$ & $53.5 \pm 13.4^{3}$ & $48.4 \pm 10.5$ & $50.1 \pm 11.7$ \\
\hline MUFA (\% TEI) & $19.8 \pm 4.7$ & $20.1 \pm 3.1$ & $20.0 \pm 3.9^{\prime}$ & $23 . \pm 3.5^{3}$ & $22.2 \pm 3.7^{2}$ & $22.5 \pm 3.6$ \\
\hline PUFA (g/day) & $7.5 \pm 1.9$ & $8.2 \pm 2.8$ & $7.9 \pm 2.4^{1}$ & $10.7 \pm 5.6^{3}$ & $9.2 \pm 3.1$ & $9.7 \pm 4.1$ \\
\hline PUFA (\% TEI) & $3.4 \pm 0.8$ & $3.8 \pm 1.1$ & $3.6 \pm 1.0^{1}$ & $4.1 \pm 1.1$ & $4.2 \pm 1.4$ & $4.2 \pm 1.3$ \\
\hline PUFA/SFA & $0.47 \pm 0.13$ & $0.46 \pm 0.13$ & $0.47 \pm 0.13^{\prime}$ & $0.51 \pm 0.14$ & $0.55 \pm 0.20^{2}$ & $0.54 \pm 0.18$ \\
\hline Cholesterol (mg/day) & $127.4 \pm 100.1$ & $101.4 \pm 76.1$ & $113.6 \pm 88.1$ & $94.3 \pm 84.1$ & $109.8 \pm 98.9$ & $104.6 \pm 93.5$ \\
\hline Carbohydrates (g/day) & $251 \pm 43$ & $244 \pm 44$ & $248 \pm 42$ & $253 \pm 35$ & $236 \pm 28$ & $242 \pm 31$ \\
\hline Sucrose (g/day) & $34 \pm 22$ & $33 \pm 22$ & $33 \pm 22^{\prime}$ & $18 \pm 12^{3}$ & $25 \pm 23$ & $23 \pm 20$ \\
\hline Fibres (g/day) & $25 \pm 5$ & $24 \pm 7$ & $24 \pm 6$ & $29 \pm 7^{3}$ & $25 \pm 5$ & $27 \pm 7$ \\
\hline
\end{tabular}

Notes: ' $\mathrm{p}<0.05$ between Arab and Berber groups; ${ }^{2} \mathrm{p}<0.05$ between Arab and Berber women; ${ }^{3} \mathrm{p}<0.05$ between Arab and Berber men.

Abbreviations: AP/VP, animal protein/vegetal protein ratio; MUFA, monounsaturated fatty acid; SFA, saturated fatty acid; PUFA, polyunsaturated fatty acid; TEl, total energy intake; PUFA/SFA = poly unsaturated fatty acid-saturated fatty acid ratio. 
The genotype distributions for these SNPs were found to be in Hardy-Weinberg equilibrium for these populations. The allelic distributions for PstI, NsiI, and BstnI polymorphisms in cases and control groups are summarized in Table 3 . The comparison of the allelic distribution between the four subgroups has demonstrated a significant difference $(\mathrm{p}<0.05)$ for the NsiI polymorphism of the INSR gene and BstnI polymorphism of IRS1 gene only for the Berber group. The effect of the NsiI G and A alleles $\left(\mathrm{OR}_{\text {INSR Nsil G }}=0.52,95 \%\right.$ CI: $0.26-2.01 ; \mathrm{p}=0.037$ and $\mathrm{OR}_{\text {INSR Nsil A }}=1.93,95 \% \mathrm{CI}$ : $0.99-3.79 ; \mathrm{p}=0.037$, respectively) seems to be protective against T2DM in Berbers only.

Genotype distribution for these polymorphisms in T2DM cases and control groups were summarized in Table 4. It appeared that INSR NsiI $(G / G)$ and IRSIBstnI (G/A) SNPs could be protective against T2DM $\left(\mathrm{OR}_{I N S R N \text { sil } G / G}=0.48,95 \%\right.$ CI: $0.17-2.05 ; \mathrm{p}=0.04$ and OR ${ }_{\text {IRSIBStnI } G / A}=0.37,95 \% \mathrm{CI}$ : $0.14-2.02 ; p=0.032$, respectively) in Berbers, since these genotypes were more frequent in healthy controls than in Berber T2DMs (67\% versus 57\%, 5\% for NsiI [G/G] and $18.33 \%$ versus $37.5 \%$ for $B \sin I[\mathrm{G} / \mathrm{A}])$. The $P$ stI SNP was not associated with T2DM in either of these two subgroups.

\section{Discussion}

In the present work, we investigated the effect of lifestyle and socioeconomic factors on T2DM occurrence, in association with genetic polymorphisms. Our choice of Arab and Berber ethnic groups of Djerba Island is based on previous observations indicating that these populations, though living in the same environment and displaying the same genetic background, have different lifestyles in terms of activity, culture, lifestyle, and nutrition. The Berber and Arab communities, which constitute a minority of the Tunisian population, are isolated from the other two population groups who have settled in the villages of the Djerba Island. ${ }^{26,27} \mathrm{We}$ have focused on the PstI, NsiI, and BstnI, restrictions sites of the insulin, insulin receptor, and insulin receptor substrate 1 genes, respectively. These genes are known to play a key role in glucose and lipid metabolism.

We examined possible correlations between these polymorphisms and the predisposition to T2DM. We have shown that the healthy Arab and Berber populations display the same allelic and genotypic distributions and that the Pst1 polymorphism of the INS gene is not associated with T2DM in either studied groups. In fact, it has been reported that polymorphisms in a variable number of tandem repeat (VNTR) sequences in INS, the insulin gene, cause type 1 diabetes. ${ }^{28}$ This region regulates insulin gene transcription thus providing a mechanism whereby this gene may be related to hyperinsulinemia, and thereby to T2DM or metabolic syndrome. Polymorphisms in INS are associated with T2DM in some populations, ${ }^{29}$ but not in others. ${ }^{30}$

On the other hand, we found an association of NsiI insulin receptor gene polymorphism with T2DM in the Berber group. In the literature, mutations of the insulin-receptor gene have been reported in patients with the rare syndrome of severe insulin resistance that contributes to noninsulin-dependent diabetes mellitus. ${ }^{31}$ Polymorphisms in this receptor gene are associated in some populations with T2DM, insulin resistance, ${ }^{32}$ and hypertension.

Finally we have shown that the BstnI Gly 972 Arg polymorphism of the insulin receptor substrate 1 is associated

Table 3 Allelic distribution of Psti, Nsi, and Bstni polymorphisms in Arabs and Berbers of Djerba Island

\begin{tabular}{|c|c|c|c|c|c|c|c|}
\hline \multirow[b]{2}{*}{$\begin{array}{l}\text { Gene } \\
\text { symbol }\end{array}$} & \multirow[b]{2}{*}{ Alleles } & \multicolumn{2}{|c|}{$\begin{array}{l}\text { Djerbian diabetic patients } \\
N=162\end{array}$} & \multicolumn{2}{|c|}{$\begin{array}{l}\text { Djerbian controls } \\
\mathbf{N}=1 / 10\end{array}$} & \multirow[b]{2}{*}{$\begin{array}{l}\text { Arab patients vs Arab } \\
\text { controls } \mathrm{P} \text { value, OR } \\
\text { (confidence Interval) }\end{array}$} & \multirow[b]{2}{*}{$\begin{array}{l}\text { Berber patients vs Berber } \\
\text { controls } \mathrm{P} \text { value, OR } \\
\text { (confidence Interval) }\end{array}$} \\
\hline & & $\begin{array}{l}\text { Arabs } \\
\mathrm{N}=102 \%\end{array}$ & $\begin{array}{l}\text { Berbers } \\
N=60 \%\end{array}$ & $\begin{array}{l}\text { Arabs } \\
\mathrm{N}=70 \%\end{array}$ & $\begin{array}{l}\text { Berbers } \\
N=40 \%\end{array}$ & & \\
\hline & Pst I & & & & & & \\
\hline \multirow[t]{3}{*}{ INS } & G & 93.63 & 92.5 & 91.43 & 87.5 & NS & NS \\
\hline & A & 6.37 & 7.5 & 8.57 & 12.5 & NS & NS \\
\hline & Nsil & & & & & & \\
\hline \multirow[t]{3}{*}{ INSR } & G & 72.55 & 60.83 & 74.28 & 75 & NS & $\mathrm{P}=0.037 ; \mathrm{OR}=0.52(0.26-2.0 \mathrm{I})$ \\
\hline & $\mathbf{A}$ & 27.45 & 39.17 & 25.72 & 25 & NS & $\mathrm{P}=0.037 ; \mathrm{OR}=1.93(0.99-3.79)$ \\
\hline & Bstn I & & & & & & \\
\hline \multirow[t]{2}{*}{ IRSI } & G & 83.82 & 89.17 & 84.28 & 81.25 & NS & NS \\
\hline & A & 16.18 & 10.83 & 17.72 & 18.75 & NS & NS \\
\hline
\end{tabular}

Notes: Nominal value for comparison, $\mathrm{p} \leq 0.05$; degree of freedom $=1$.

Abbreviations: NS, not significant; OR, odds ratio. 
Table 4 Genotypic distribution of, Pstl, Nsil, and Bstnl polymorphisms in Arabs and Berbers of Djerba Island

\begin{tabular}{|c|c|c|c|c|c|c|c|}
\hline \multirow[b]{2}{*}{$\begin{array}{l}\text { Gene } \\
\text { symbol }\end{array}$} & \multirow[b]{2}{*}{ Genotypes } & \multicolumn{2}{|c|}{ Diabetic patients $N=162$} & \multicolumn{2}{|c|}{ Controls $\mathbf{N}=1 \mathrm{I} 0$} & \multirow[b]{2}{*}{$\begin{array}{l}\text { Arab diabetics vs Arab } \\
\text { controls } \mathrm{P} \text { value; OR } \\
\text { (confidence interval) }\end{array}$} & \multirow[b]{2}{*}{$\begin{array}{l}\text { Berber diabetics vs Berber } \\
\text { controls } \mathrm{P} \text { value; OR } \\
\text { (confidence interval) }\end{array}$} \\
\hline & & $\begin{array}{l}\text { Arabs } \\
\mathrm{N}=102 \%\end{array}$ & $\begin{array}{l}\text { Berbers } \\
N=60 \%\end{array}$ & $\begin{array}{l}\text { Arabs } \\
n=70 \%\end{array}$ & $\begin{array}{l}\text { Berbers } \\
n=40 \%\end{array}$ & & \\
\hline & Pstl & & & & & & \\
\hline \multirow[t]{4}{*}{ INS } & $\mathrm{G} / \mathrm{G}$ & 87.25 & 85 & 82.86 & 75 & NS & NS \\
\hline & $\mathrm{G} / \mathrm{A}$ & 12.75 & 15 & 17.14 & 25 & NS & NS \\
\hline & $\mathrm{A} / \mathrm{A}$ & 0 & 0 & 0 & 0 & NS & NS \\
\hline & Nsil & & & & & & $P=0.04 ; O R=0.43$ \\
\hline \multirow[t]{4}{*}{ INSR } & $\mathrm{G} / \mathrm{G}$ & 51.96 & 36.67 & 54.28 & 57.5 & NS & $(0.17-2.05)$ \\
\hline & $\mathrm{G} / \mathrm{A}$ & 41.17 & 48.33 & 40 & 35 & NS & NS \\
\hline & $\mathrm{A} / \mathrm{A}$ & 6.87 & 15 & 5.72 & 7.5 & NS & NS \\
\hline & Bstnl & & & & & & \\
\hline \multirow[t]{4}{*}{ IRSI } & $G / G$ & 67.65 & 80 & 68.57 & 62.5 & NS & NS \\
\hline & $G / A$ & 32.35 & 18.33 & 31.43 & 37.5 & NS & $P=0.032 ; O R=0.37$ \\
\hline & $A / A$ & 0 & 1.67 & 0 & 0 & NS & $(0.14-2.02)$ \\
\hline & & & & & & & NS \\
\hline
\end{tabular}

Notes: Nominal value for comparison, $\mathrm{p} \leq 0.05$; degree of freedom $=1$.

Abbreviation: NS, not significant.

with T2DM only among Berbers. As reported in the literature, mutations of the insulin-receptor substrate gene have been described in patients with the rare syndrome of severe insulin resistance that contributes to noninsulin-dependent diabetes mellitus. ${ }^{33,34}$ Indeed several studies have reported a higher frequency of the IRS1 Arg 972 polymorphism among T2DM patients, while others have reported a weak association or its absence between this variant and T2DM. ${ }^{35}$ The IRSI Arg 972 polymorphism is absent in Pima Indians and other subpopulations. ${ }^{36-38}$ In both diabetic and control Japanese populations, the prevalence of the Arg 972 polymorphism appears to be lower than that observed in Caucasian populations. ${ }^{39}$ These results may account for the ethnic differences in the genetic background for T2DM. There were no differences between males and females in their respective clinical and biochemical findings, although there was a slightly higher prevalence of obesity in Berber women (based on BMI, height, and weight data), also characterized by a low education level and a low activity or sedentary lifestyle. A significant difference $(\mathrm{p}<0.05)$ in education level, sedentary lifestyle, low physical activity, and socioeconomic levels between healthy and diabetic Berber male subjects was found, suggesting that correlations may exist among these factors and risk for T2DM among Berbers. For the Arab group, no significant difference was observed between healthy and T2DM subjects. Hypertension was associated with T2DM in both groups.

To explain the differences between our results on the two Djerban groups and to distinguish genetic factors from the influence of the environment factors, we considered the nongenetic factors, ie, factors that can be controlled by behavior, (diet, activity levels/sedentary lifestyle, and obesity) implicated in the etiology of diabetes. These environmental factors are significantly different between Arabs and Berbers. The presence of some risk factors for T2DM in diabetic Berbers are related to lifestyle such as a more sedentary lifestyle, lower levels of physical activity, and lower levels of education for diabetic males who do not complete primary education and who are of a lower socioeconomic status. Berbers who have an underprivileged social background have higher rates of mortality and morbidity compared to the Arabs; they retain traditional behaviors that result in T2DM. ${ }^{40}$ Social status was found to be a risk factor for T2DM in other populations such as those in urban Sweden. ${ }^{41}$ In fact, our samples were obtained from public hospitals in villages where most patients are from a lower socioeconomic background.

We have shown that in the Berber group, low levels of education, socioeconomic status and limited physical activity are risk factors for T2DM. INSR gene NsiI G/G and IRSI gene BstnI G/A genotype are protective against T2DM. For the Arab group, these same factors are not significantly associated to T2DM. More investigation is needed to analyse the occurrence of T2DM in Arabs to determine the source of their T2DM protection, or other environmental and genetic risk factors. To our knowledge this is the first study which compares the dietary intake of Arab and Berber people. The inclusion criteria of this study reduced the influence of the socioeconomic level and 
acculturation on the food choices. These conditions were often considered as factors of variability. Low education level is a factor that exacerbates the problem of obesity in Tunisia. Women without education do not recognize the risks and health consequences associated with obesity. It is more worrisome that these women (and their male partners) consider fatness and obesity to be desirable since culturally these traits have been associated with higher social status, fertility and prosperity.

In conclusion, these results focus on some of the risk factors leading to T2DM and on the possible interactions between genetic and environmental factors. Ethnicity and differences in education level play an important role in the occurrence of the disease..$^{42}$ Berbers may constitute a group at higher risk for developing T2DM and hypertension, due to their nutritional habits. Lack of adequate dietary intake, accompanied by obesity, low physical activity and low socioeconomic levels may combine to cause this disease. These findings suggest that appropriate dietary interventions and education may ameliorate nutritional deficiencies and improve healthy behavioral lifestyles.

\section{Acknowledgments}

We are grateful to all donors of Djerba Island hospital for their participation in the study, and the collection of blood samples. We also thank all members of the Centro de Investigación Biomédica de Occidente, Instituto Mexicano Del Seguro Social, Guadalajara, Jalisco in México for their considerable help in the genetic study. We report no conflicts of interest in this work.

\section{References}

1. McCarthy MI, Froguel P. Genetic approaches to the molecular understanding of type 2 diabetes. Am J Physiol Endocrinol Metab. 2002;283:217-225.

2. Morton N, Lio E. Oligogenic linkage and map integration. In: Pawlowitzki IH, Edwards JH, Thompson EA, editors. Genetic Mapping of Disease Genes. 1st edition. San Diego, CA: Academic Press; 1997. p. 17-21.

3. De Meyts P. The diabetogenes concept of NIDDM. Adv Exp Med Biol. 1993;334:89-100.

4. Report of the Expert Committee on the Diagnosis and Classification of Diabetes Mellitus. Diabetes Care. 1997;20:1183-1197.

5. Moller DE, Bjørbæk C, Vidal Puig A. Candidate genes for insulin resistance. Diabetes Care. 1996;19:396-400.

6. Hoban PR, Kelsey AM. Pst I polymorphism within the $3^{\prime}$ untranslated region of the insulin gene detectable by the polymerase chain reaction. Nucleic Acids Res. 1991;19:4576.

7. Taylor SI, Kadowaki T, Kadowaki HD, Cama C, Keon M. Mutations in insulin-receptor gene in insulin-resistant patients. Diabetes Care. 1990;13:257-279.

8. Taylor SI. Insulin action, insulin resistance and type 2 diabetes mellitus. In: Scriver CR, Beaudet AL, Sly WS, Valle D, editors. The Metabolic and Molecular Bases of Inherited Diseases. 8th edition. New York, NY: McGraw-Hill; 2001. p. 1433-1470.
9. Bennett ST, Todd AJ. Human type 1 diabetes and the insulin gene: principles of mapping polygenes. Annu Rev Genet. 1996;30:343-370.

10. Bennett ST, Lucassen AM, Gough SC, et al. Susceptibility to human type 1 diabetes at IDDM2 is determined by tandem repeat variation at the insulin gene minisatellite locus. Nat Genet. 1995;9:284-292.

11. Schrader AP, Zee RY, Morris BJ. Association analyses of NsiI RFLP of human insulin receptor gene in hypertensives. Clin Genet. 1996;49:74-78.

12. Imai YA, Fusco Y, Suzuki, et al. Variant sequences of insulin receptor substrate-1 in patients with noninsulin-dependent diabetes mellitus. J Clin Endocrinol Metab. 1994;79:1655-1658.

13. Baroni MG, Arca F, Sentinelli F, et al. The G972R variant of the insulin receptor substrate-1 (IRS-1) gene, body fat distribution and insulinresistance. Diabetologia. 2001;44:367-372.

14. Gharbi M, Akrout M, Zouari B. Prevalence and risk factors of noninsulin-dependent diabetes mellitus in the rural and urban population of Tunisia. Rev Epidemiol Sante Publique. 2002;503:49-55.

15. Arfa I, Abid A, Malouche D, et al. Familial aggregation and excess maternal transmission of type 2 diabetes in Tunisia. Postgrad Med J. 2007;833:48-51.

16. Sánchez-Corona J, Flores-Martínez SE, Machorro-Lazo MV, et al. Polymorphisms in candidate genes for type 2 diabetes mellitus in a Mexican population with metabolic syndrome findings. Diabetes Res Clin Pract. 2004;63:47-55.

17. Vasarova de Courten B, de Courten M, Hanson RL, et al. Higher prevalence of type 2 diabetes metabolic syndrome and cardiovascular diseases in gypsies than in non-gypsies in Slovakia. Diabetes Res Clin Pract. 2003;62:95-103.

18. Knowler WC, Pettitt DJ, Saad MF, Bennett PH. Diabetes mellitus in the Pima Indians: incidence, risk factors and pathogenesis. Diabetes Metab Rev. 1990;6:1-27.

19. Arroyo P, Pardio J, Fernandez V, Vargas-Ancona L, Canul G, Loria A. Obesity and cultural environment in Yucatan region. Nutr Rev. 1999;57(5 Pt 2):S78-S82.

20. Gustincich S, Manfioletti G, Del Sal G, Schneider C, Carninci P. A fast method for high-quality genomic DNA extraction from whole human blood. Biotechniques. 1991;11:298-302.

21. Sambrook J, Fritsch EF, Maniatis T, editors. Molecular Cloning: A Laboratory Manual. 2nd edition. New York, NY: Cold Spring Harbor Laboratory Press; 1989. p. 9.1-9.62.

22. Saiki RK, Gelfand DH, Stoffel S, et al. Primer-directed enzymatic amplification of DNA with a thermostable DNA polymerase. Science. 1988;239:487-491.

23. Hoban PR, Kelsey AM. PstI polymorphism within the $3^{\prime}$ untranslated region of the insulin gene detectable by the polymerase chain reaction (INS), Nucleic Acids Res. 1991;19:45-76.

24. Schrader AP, Zee RY, Morris BJ. Association analyses of NsiI RFLP of human insulin receptor gene in hypertensives. Clin Genet. 1996;49:74-78.

25. Almind K, Bjorbaek C, Vestergaard H, Hansen T, Echwald S, Pedersen O. Aminoacid polymorphisms of insulin receptor substrate-1 in non-insulin-dependent diabetes mellitus. Lancet. 1993;342:828-832.

26. Cherni L, Pereira L, Goios A, et al. Y-chromosomal STR haplotypes in three ethnic groups and one cosmopolitan population from Tunisia. Forensic Sci Int. 2005:152:95-99.

27. Loueslati B, Cherni L, Khodjet-Elkhil H, et al. Islands inside an island: reproductive isolates on Jerba island. Am J Hum Biol. 2006;18:149-153.

28. Bennett ST, Lucassen AM, Gough SC, et al. Susceptibility to human type 1 diabetes at IDDM2 is determined by tandem repeat variation at the insulin gene minisatellite locus. Nat Genet. 1995;9:284-292.

29. Morgan R, Bishop A, Owens DR, Luzio SD, Peters JR, Rees A. Allelic variants at insulin-receptor and insulin gene loci and susceptibility to NIDDM in Welsh population. Diabetes. 1990;39:1479-1484.

30. Given BD, Mako ME, Tager HS, et al. Diabetes due to secretion of an abnormal insulin. N Engl J Med. 1980;302:129-135.

31. Seino S, Bell GI. Alternative splicing of human insulin receptor messenger RNA. Biochem Biophys Res Commun. 1989;159:312-316. 
32. Engstrom G, Jerntorp I, Pessah-Rasmussen H, Hedblad B, Berglund G, Janzon L. Geographic distribution of stroke incidence within an urban population: relations to socioeconomic circumstances and prevalence of cardiovascular risk factors. Stroke. 2001;32:1098-1103.

33. Baroni MG, Arca M, Sentinelli F, et al. The G972R variant of the insulin receptor substrate-1 (IRS-1) gene, body fat distribution and insulin-resistance. Diabetologia. 2001;44:367-372.

34. Clausen JO, Hansen T, Bjorbaek C, et al. Insulin resistance: interactions between obesity and a common variant of insulin receptor substrate-1. Lancet. 1995;346:397-402.

35. Lei HH, Coresh J, Shuldiner AR, Boerwinkle E, Brancati FL. Variants of the insulin receptor substrate-1 and fatty acid binding protein 2 genes and the risk of type 2 diabetes, obesity, and hyperinsulinemia in African-Americans: the Atherosclerosis Risk in Communities Study. Diabetes. 1999;48:1868-1872.

36. Chuang LM, Lai CS, Yeh JI, Wu HP, Tai TY, Lin BJ. No association between the Gly971Arg variant of the insulin receptor substrate 1 gene and NIDDM in the Taiwanese population. Diabetes Care. 1996; 19:446-449.
37. van Dam RM, Hoebee B, Seidell JC, Schaap MM, Blaak EE, Feskens EJ. The insulin receptor substrate-1 Gly972Arg polymorphism is not associated with type 2 diabetes mellitus in two populationbased studies. Diabet Med. 2004;21:752-758.

38. Celi FS, Silver K, Walston J, Knowler WC, Bogardus C, Shuldiner AR. Lack of IRS-1 codon 513 and 972 polymorphism in Pima Indians. J Clin Endocrinol Metab. 1995;80:2827-2829.

39. Ura S, Araki E, Kishikawa H, et al. Molecular scanning of the insulin receptor substrate-1 (IRS-1) gene in Japanese patients with NIDDM identification of five novel polymorphisms. Diabetologia. 1996;39:600-608.

40. Yacoubi Loueslati B, Ennafaa H, Ben Amor M, et al. [Mitochondrial DNA polymorphism reveals a genetic differentiation between ethnic groups in the population of Jerba]. Arch Inst Pasteur Tunis. 1998;75:9-18.

41. Andersson CM, Bjaras G, Tillgren P, Ostenson G. Local media monitoring in process evaluation. Experiences from the Stockholm Diabetes Prevention Programme. J Health Commun. 2007;3:269-283.

42. Bassuk SS, Manson JE. Epidemiological evidence for the role of physical activity in reducing risk of type 2 diabetes and cardiovascular disease. J Appl Physiol. 2005;99:1193-1204.

\section{Publish your work in this journal}

Pharmacogenomics and Personalized Medicine is an international, peer-reviewed, open access journal characterizing the influence of genotype on pharmacology leading to the development of personalized treatment programs and individualized drug selection for improved safety, efficacy and sustainability. This journal is indexed on the

\section{Dovepress}

American Chemical Society's Chemical Abstracts Service (CAS). The manuscript management system is completely online and includes a very quick and fair peer-review system, which is all easy to use. Visit http://www.dovepress.com/testimonials.php to read real quotes from published authors.

Submit your manuscript here: http://www.dovepress.com/pharmacogenomics-and-personalized-medicine-journal 